\title{
Thrombosed traumatic aneurysm of the occipital artery: a case report and review of the literature
}

\author{
Vikas Y Rao', Steven W Hwang ${ }^{2}$, Adekunle M Adesina ${ }^{3}$ and Andrew Jea ${ }^{\text {** }}$
}

\begin{abstract}
Introduction: Occipital artery aneurysms are very rare vascular lesions. Most cases reported in the literature have been post-traumatic pseudoaneurysms of the occipital artery.

Case presentation: We report the case of a 14-year-old Caucasian boy presented with a painless non-pulsatile scalp mass that developed rapidly after minor blunt head trauma. The scalp mass was excised six months after the trauma. A pathologic diagnosis of a thrombosed true aneurysm was made. Our patient has had no recurrence of the mass at 15 months follow-up.

Conclusions: We present a case of a true aneurysm of the occipital artery following minor head trauma. We review the literature for similar cases and discuss the difficulty of establishing a diagnosis prior to surgical intervention.
\end{abstract}

\section{Introduction}

Aneurysms of the external carotid circulation are rare. Of these aneurysms, scalp aneurysms involving the occipital artery are the rarest. They have been described primarily as a consequence of blunt, penetrating or iatrogenic trauma. There are also cases secondary to infection and autoimmune disease, and cases of spontaneous aneurysms of idiopathic etiology.

Pathologic examination of these lesions reveals that the majority are pseudoaneurysms, the dilated walls of which are comprised of only the outer layers of the native vessel wall. These lesions usually present as pulsatile scalp masses and are often painless.

Only 10 cases of traumatic and spontaneous aneurysm of the occipital artery have been previously reported in the English literature, with sporadic cases in other languages. Of these previously reported cases, only one was confirmed to be a true aneurysm of the occipital artery, comprising all layers of the arterial wall. We report another case of a true aneurysm of the occipital artery in a pediatric patient.

\section{Case presentation}

A 14-year-old Caucasian boy presented to our Pediatric Neurosurgery clinic for evaluation of a scalp mass. Our

\footnotetext{
*Correspondence: ajea@bcm.edu

'Division of Pediatric Neurosurgery, Texas Children's Hospital, Department of Neurosurgery, Baylor College of Medicine, Houston, TX, USA

Full list of author information is available at the end of the article
}

patient was a previously healthy child who had a basketball strike to the back of his head four months prior to presentation. Our patient did not have loss of consciousness and had immediate scalp swelling near the impact site. While initially painful, the pain subsided over the next two days, but a firm mass persisted for months after the incident. He was then sent to our Pediatric Neurosurgery clinic for evaluation of the persistent mass.

On examination, our patient was found to have a $2.5 \mathrm{~cm}$ firm, non-tender, non-pulsatile, mobile mass in the left posterior temporal area approximately $6.5 \mathrm{~cm}$ superior to the mastoid tip and $4.5 \mathrm{~cm}$ lateral to the external occipital protuberance. The mass was not bothersome to our patient other than it being unsightly. Upon palpation, no palpable thrill was present, and we did not auscultate the lesion. A skull X-ray showed no bony abnormalities. A magnetic resonance imaging scan showing heterogeneity within the lesion suggested partial thrombosis of the scalp mass or evolving hematoma of differing ages (Figure 1). Due to the very mild symptoms, the decision was made to observe the lesion. Two months later, however, our patient returned with cosmetic concerns related to the mass. Surgery was offered to remove the lesion and provide a definitive diagnosis.

Our patient was brought to the operating room, and a curvilinear skin incision was made superior to the mass. The firm, smooth, non-pulsatile mass was encountered just under the galea aponeurotica. It was circumferentially 

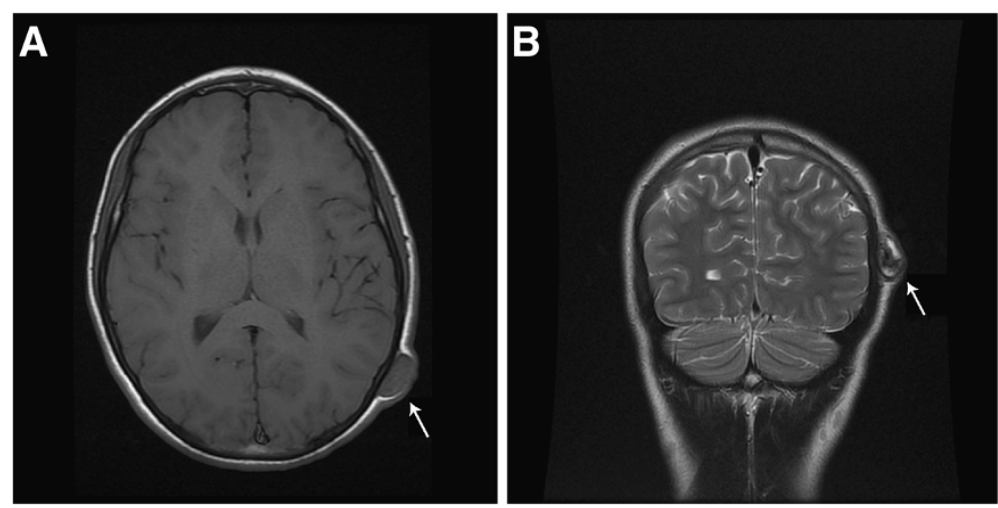

Figure 1 Preoperative T1-weighted axial and T2-weighted coronal magnetic resonance imaging. (A) Preoperative T1-weighted axial magnetic resonance imaging and (B) T2-weighted coronal magnetic resonance imaging shows an evolving hematoma (arrow) in the vicinity of the occipital artery.

dissected and associated with brisk arterial bleeding from vessels proximal and distal to the lesion. We had not anticipated an aneurysm and, therefore, encountered significant bleeding until the proximal and distal arteries were coagulated. The bleeding was easily controlled with bipolar electrocautery and division of the proximal and distal artery. The mass was excised en bloc and sent for pathologic examination. However, we did not section the mass on the operating table to look for intraluminal thrombosis. Our patient tolerated the procedure well and was sent home later the same day.

Gross examination of the specimen demonstrated a smooth, fluctuant, intact cyst (Figure 2). Sectioning revealed a thin, tan-white wall and red-purple, soft-tofriable contents. Microscopic examination showed a well-circumscribed thrombosed artery with fibrosis and granulation tissue (Figure 3). The lumen was filled with hemorrhage, fibrin and abundant papillary structures with fibrinous cores lined by a single layer of endothelial cells. There was no cytologic atypia, mitosis or necrosis of the endothelial cells. Movat's pentachrome stain highlighted elastic lamina, consistent with the wall of an artery.

Our patient returned to our Pediatric Neurosurgery clinic for follow-up, and at 15 months has had no recurrence of this mass.

\section{Discussion}

Aneurysms of the terminal branches of the external carotid artery are rare. They are generally the results of blunt, penetrating or iatrogenic trauma but can also be associated with infections. Traumatic aneurysms usually develop two to six weeks after blunt head trauma. Pseudoaneurysms are more common in the scalp and do not involve all layers of the arterial wall. True aneurysms,
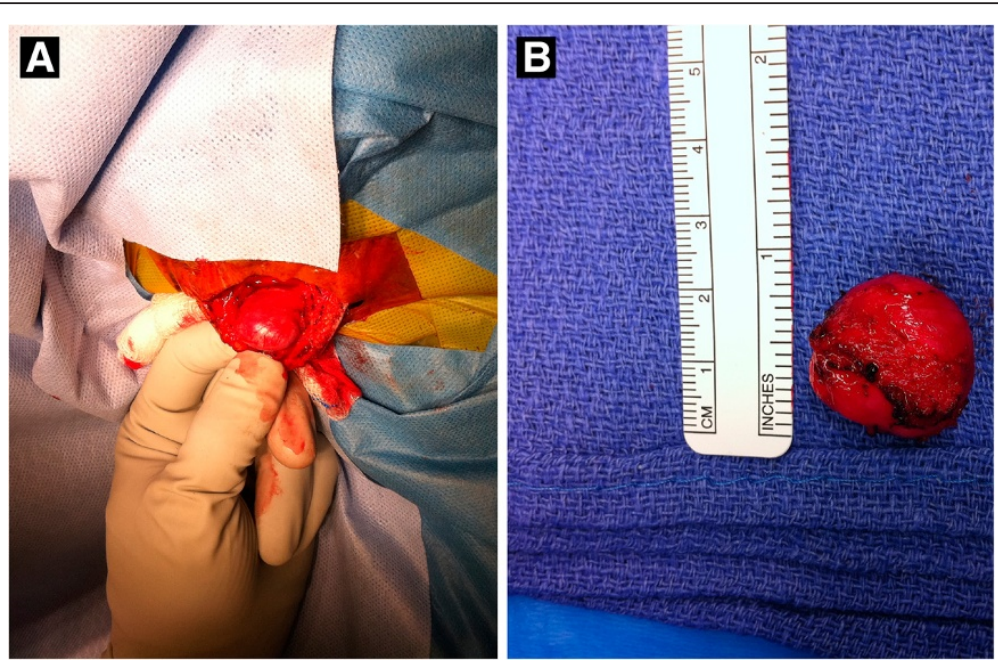

Figure 2 Intraoperative photograph. Intraoperative photograph shows (A) the thrombosed non-pulsatile occipital artery aneurysm and (B) specimen after en bloc excision. 


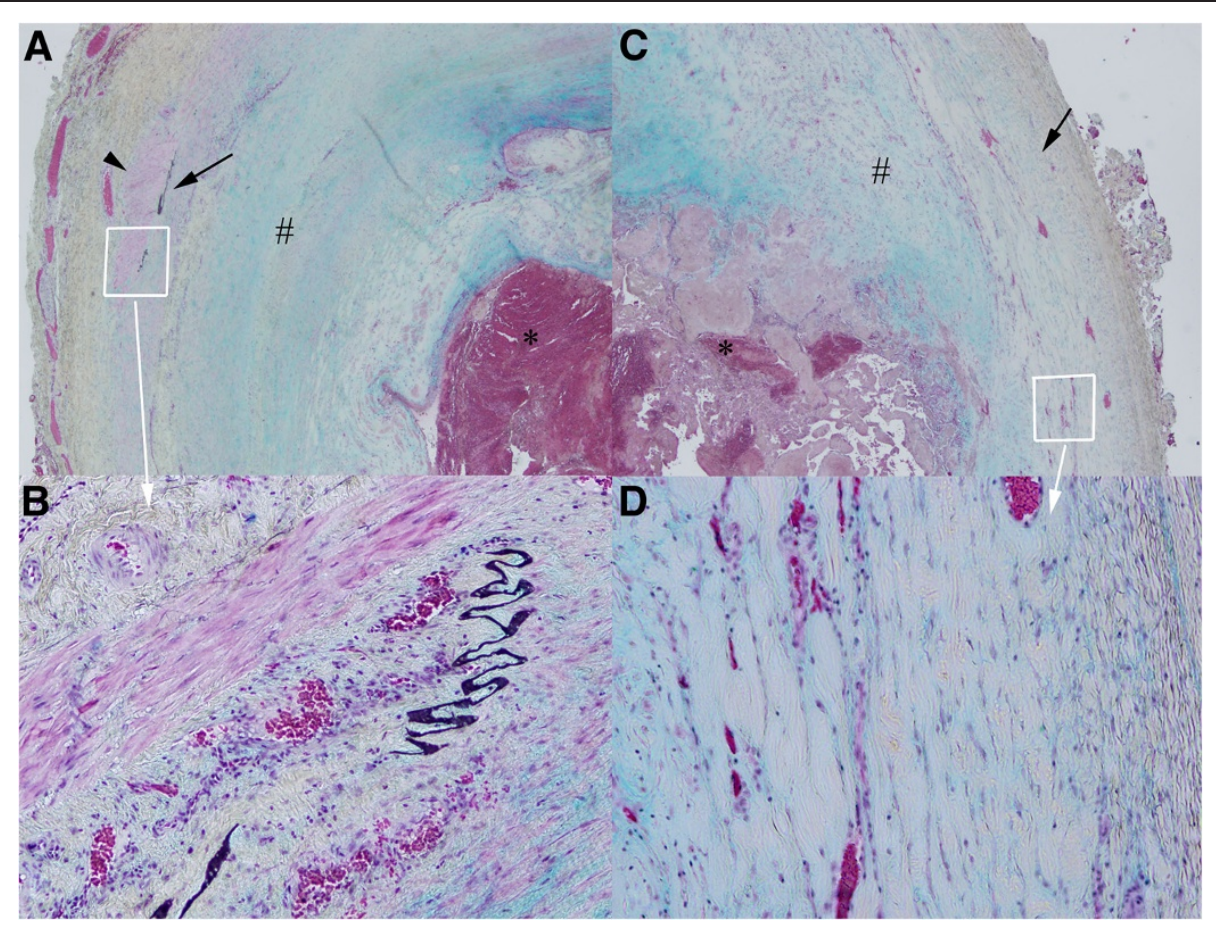

Figure 3 Histopathologic examination shows a true aneurysm. Histopathologic examination demonstrates a true aneurysm which includes all three layers of the arterial wall: the intima, media and adventitia. (A) and (C) show the artery under 20x magnification with intraluminal thrombus $(*)$ and thickened intima (\#). Residual smooth muscle fibers of the media are also seen (arrow head) in $(\mathbf{A})$. (C) shows a portion of the arterial wall dilated by the aneurysm. (B) and (D) are 100x magnifications of the margin of (A) and (B).

however, involve all three vessel layers - the intima, media and adventitia - and represent a localized or diffuse dilatation of the vessel wall.

The occipital artery has three segments. From proximal-to-distal-most, they are the digastric, suboccipital and subgaleal segments. At the level of the superior nuchal line, the suboccipital segment of the artery crosses the sagittal plane, intersecting the midpoint of the lambdoid suture on the ipsilateral side [1]. Here, the artery becomes vulnerable to blunt trauma because of its exposed position overlying the occipital bone.

There have only been 10 previous reports of traumatic and spontaneous aneurysm of the occipital artery (Table 1). Six cases of occipital artery aneurysm were identified as pseudoaneurysms during pathologic examinations. Only one previously reported case of a true occipital artery aneurysm has been reported: atherosclerotic change and hemodynamic stress to the arterial wall may have contributed to its development in a 51-year-old man [2]. Congenital vulnerabilities of the arterial wall, such as defects of the elastic membrane, may contribute to the development of a true aneurysm after minor head trauma, as may have been the case in our patient [3].

This disorder may not be readily diagnosed based on history and physical examination, especially if the scalp mass is a thrombosed, non-pulsatile vascular lesion. A high degree of clinical suspicion is required to recognize an occipital artery aneurysm or pseudoaneurysm. Differential diagnosis of the occipital scalp mass should include dermoid or epidermoid cyst, eosinophilic granuloma, hematoma, abscess, aneurysm, arteriovenous fistula, encephalocele, lymphoid hyperplasia and sinus pericranii [11]. While, in most cases, surgical resection of this lesion is a straightforward procedure with low morbidity, an issue may arise in young pediatric patients for whom blood loss is a significant concern. For this reason, physicians should take care not to miss this pathology in the pediatric population.

If clinically suspected, other diagnostic tools may be essential for correct diagnosis. Duplex ultrasound shows fusiform dilation and turbulent intraluminal arterial flow in non-thrombosed aneurysms [12]. Computed tomography angiography can provide important information on the vessel of origin, luminal morphology and relationship to adjacent osseous and soft tissue structures [13]. Conventional angiography is considered the gold standard for defining these lesions and differentiating them from arteriovenous malformations, which also present as pulsatile subcutaneous masses [14]; however, it may be less useful in cases of thrombosed aneurysms. 
Table 1 Ten previously reported cases of occipital artery aneurysms, including the current case

\begin{tabular}{|c|c|c|c|c|c|}
\hline Author/year & $\begin{array}{l}\text { Age } \\
\text { (years)/sex }\end{array}$ & Presentation/etiology & Procedure & Pathology & Follow-up \\
\hline Yang et al., 2005 [4] & $85 \mathrm{~F}$ & $\begin{array}{l}\text { Post-traumatic. At two weeks } \\
\text { post-injury non-tender, non-pulsatile } \\
\text { mass noted. Patient then presented } \\
\text { two months later with scalp bleeding } \\
\text { from mass eroding through skin. }\end{array}$ & $\begin{array}{l}\text { Direct puncture } \\
\text { embolization }\end{array}$ & $\begin{array}{l}\text { No formal } \\
\text { pathology }\end{array}$ & $\begin{array}{l}\text { Resolution of symptoms. } \\
\text { No recurrence at six months. }\end{array}$ \\
\hline Aquilina et al., 2005 [1] & $15 \mathrm{M}$ & $\begin{array}{l}\text { Post-traumatic. Painful, enlarging, } \\
\text { pulsatile mass four weeks after } \\
\text { injury with occipital headache. }\end{array}$ & Resection & Pseudoaneurysm & $\begin{array}{l}\text { Postoperative resolution } \\
\text { of symptoms. }\end{array}$ \\
\hline $\begin{array}{l}\text { Tambasco et al., } \\
2007[5]\end{array}$ & $68 \mathrm{~F}$ & $\begin{array}{l}\text { latrogenic after deep brain stimulation } \\
\text { lead tunneling. Painful pulsatile mass } \\
\text { two weeks after surgery. }\end{array}$ & $\begin{array}{l}\text { Endovascular } \\
\text { embolization }\end{array}$ & $\begin{array}{l}\text { No formal } \\
\text { pathology }\end{array}$ & $\begin{array}{l}\text { Non-pulsatile immediately } \\
\text { after embolization. Mass } \\
\text { disappeared in one month. }\end{array}$ \\
\hline Anan et al., 2008 [6] & $81 \mathrm{~F}$ & $\begin{array}{l}\text { Post-traumatic. Two years after injury, } \\
\text { incidentally discovered during workup } \\
\text { of brain metastasis. }\end{array}$ & No intervention & $\begin{array}{l}\text { Pathology } \\
\text { unknown }\end{array}$ & $\begin{array}{l}\text { Stable on angiography two } \\
\text { years after incidental discovery. }\end{array}$ \\
\hline Patel et al., 2008 [7] & $85 \mathrm{~F}$ & $\begin{array}{l}\text { Post-traumatic. Three weeks after injury, } \\
\text { presented with pulsatile, firm, } \\
\text { non-tender mass. }\end{array}$ & No intervention & $\begin{array}{l}\text { Pathology } \\
\text { unknown }\end{array}$ & $\begin{array}{l}\text { Mass involuted during } \\
\text { observation period. No } \\
\text { recurrence at one year. }\end{array}$ \\
\hline John et al., 2009 [8] & $16 \mathrm{M}$ & $\begin{array}{l}\text { Post-traumatic. Painful, enlarging, } \\
\text { pulsatile mass six months after injury. }\end{array}$ & Resection & Pseudoaneurysm & $\begin{array}{l}\text { Resolution of symptoms. } \\
\text { No recurrence at one year. }\end{array}$ \\
\hline \multirow[t]{2}{*}{$\begin{array}{l}\text { Kanematsu et al., } \\
2010[9]\end{array}$} & $48 \mathrm{M}$ & $\begin{array}{l}\text { Spontaneous, NF-1 associated. Patient } \\
\text { presented with painful neck swelling } \\
\text { and bleeding after rupture of } \\
\text { spontaneous aneurysm of occipital } \\
\text { artery. }\end{array}$ & $\begin{array}{l}\text { Endovascular coil } \\
\text { embolization }\end{array}$ & $\begin{array}{l}\text { No formal } \\
\text { pathology }\end{array}$ & $\begin{array}{l}\text { Bleeding stopped by } \\
\text { procedure. No recurrence } \\
\text { at } 28 \text { months. }\end{array}$ \\
\hline & $39 M$ & $\begin{array}{l}\text { Spontaneous, NF-1 associated. Patient } \\
\text { presented with painful neck after } \\
\text { rupture of spontaneous aneurysm of } \\
\text { occipital artery. }\end{array}$ & $\begin{array}{l}\text { Endovascular coil } \\
\text { embolization }\end{array}$ & $\begin{array}{l}\text { No formal } \\
\text { pathology }\end{array}$ & No recurrence at six months. \\
\hline Kim et al., 2010 [2] & $51 \mathrm{M}$ & $\begin{array}{l}\text { Spontaneous. Painless, pulsatile scalp } \\
\text { mass in left occipital area; no history } \\
\text { of trauma. }\end{array}$ & Resection & True aneurysm & $\begin{array}{l}\text { Four months without } \\
\text { radiographic evidence of } \\
\text { recurrence. }\end{array}$ \\
\hline Kim et al., 2010 [10] & $36 \mathrm{M}$ & $\begin{array}{l}\text { Spontaneous. Pulsatile mass in right } \\
\text { suboccipital region for one year with } \\
\text { no history of trauma. }\end{array}$ & Resection & Pseudoaneurysm & $\begin{array}{l}\text { Unknown. Follow-up not } \\
\text { reported. }\end{array}$ \\
\hline Present case & $14 \mathrm{M}$ & $\begin{array}{l}\text { Post-traumatic. Non-pulsatile painless } \\
\text { scalp mass at site of injury two } \\
\text { months prior. Excised at four months } \\
\text { due to persistence. }\end{array}$ & Resection & True aneurysm & $\begin{array}{l}\text { Resolution of symptoms. } \\
\text { No recurrence at } 15 \text { months. }\end{array}$ \\
\hline
\end{tabular}

$F$ female, $M$ male, $N F-1$ neurofibromatosis type 1.

Although the natural history of this rare lesion is unknown, indications in the treatment of occipital artery aneurysm have included reduced risk of hemorrhage, pain relief and, in most cases, the alleviation of cosmetic disfigurement. In our case, the indication for surgery was for definitive pathologic diagnosis of the scalp mass and cosmesis. Treatment options for occipital aneurysms include simple resection, proximal ligation of the parent artery, trapping of the aneurysm, percutaneous ultrasoundguided thrombosis of the lesion, and endovascular arterial embolization or coil occlusion $[7,15]$.

\section{Conclusions}

Aneurysms of the occipital artery are rare, and the majority of them are pseudoaneurysms. When true aneurysms do occur, they present as painless swelling.
Neurological complications are exceedingly rare. The diagnosis may be made preoperatively by careful physical examination if the clinical suspicion is high. In other instances, however, the diagnosis of an aneurysm is not made until pathologic review after surgical resection of the scalp mass. Preoperative diagnosis is especially difficult in the case of thrombosed aneurysms. Surgical resection is generally curative. Care should be taken in very young children due to a potential for blood loss during surgery.

\section{Consent}

Written informed consent was obtained from the patient's parents for publication of this case report and accompanying images. A copy of the written consent is 
available for review by the Editor-in-Chief of this journal.

\section{Competing interests}

The authors declare that they have no competing interests.

\section{Authors' contributions}

VYR and AJ drafted the manuscript for important intellectual content. VYR, SWH, AMA and AJ made substantial editorial revisions to the manuscript. AJ made major contributions to conception and design. All authors read and approved the final manuscript.

\section{Author details}

'Division of Pediatric Neurosurgery, Texas Children's Hospital, Department of Neurosurgery, Baylor College of Medicine, Houston, TX, USA. ${ }^{2}$ Division of Pediatric Neurosurgery, Department of Neurosurgery, Floating Hospital for Children, Tufts Medical Center, Boston, MA, USA. ${ }^{3}$ Division of Neuropathology, Texas Children's Hospital, Department of Pathology, Baylor College of Medicine, Houston, TX, USA.

Received: 20 February 2012 Accepted: 27 April 2012

Published: 17 July 2012

\section{References}

1. Aquilina K, Carty F, Keohane C, Kaar GK: Pseudoaneurysm of the occipital artery: an unusual cause of persisting headache after minor head injury. Ir Med J 2005, 98:215-217.

2. Kim HS, Son BC, Lee SW, Kim IS: A rare case of spontaneous true aneurysm of the occipital artery. J Korean Neurosurg Soc 2010, 47:310-312.

3. Kawabori M, Kuroda S, Nakayama N, Kenmotsu Y, Shimizu H, Tanino M, Iwasaki Y: Spontaneous giant aneurysm of the superficial temporal artery: case report. Neurol Med Chir (Tokyo) 2009, 49:198-201.

4. Yang HJ, Choi YH: Posttraumatic pseudoaneurysm in scalp treated by direct puncture embolization using N-Butyl-2-cyanoacrylate: a case report. Korean J Radiol 2005, 6:37-40.

5. Tambasco N, Hamam M, Castrioto C, Calabresi P, Rossi A: Occipital pseudoaneurysm as a complication of extension channel placement for DBS in Parkinson's disease. Mov Disord 2007, 22:1834-1836.

6. Anan M, Kamida T, Abe T, Fujiki M: A rare case of a traumatic aneurysm of the occipital artery: a brief report. Neurosurg Q 2008, 18:64.

7. Patel M, Tchelepi H, Rice DH: Traumatic pseudoaneurysm of the occipital artery: case report and review of the literature. Ear Nose Throat $J$ 2008, 87: E7-E12.

8. John N, Leach JL, Rachana T, Mangano FT: Traumatic aneurysm of the occipital artery secondary to paintball injury. Clin Neurol Neurosurg 2009, 111:105-108.

9. Kanematsu M, Kato H, Kondo H, Goshima S, Tsuge Y, Kojima T, Watanabe H: Neurofibromatosis type 1: transcatheter arterial embolization for ruptured occipital arterial aneurysms. Cardiovasc Intervent Radiol 2010, Epub ahead of print.

10. Kim SK, Hwang SC, Kim BT: Usefulness of three-dimensional CT angiography as a confirmatory diagnostic test for scalp pseudoaneurysms. Korean J Cerebrovasc Surg 2010, 12:87-90.

11. De Vogelaere K: Traumatic aneurysm of the superficial temporal artery: case report. J Trauma 2004, 57:399-401.

12. Reddick EJ, Andersen CA: Superficial temporal artery aneurysms: an important preoperative diagnosis. Mil Med 1981, 146:405-406.

13. Walker MT, Liu BP, Salehi SA, Badve S, Batjer HH: Superficial temporal artery pseudoaneurysm: diagnosis and preoperative planning with $C T$ angiography. AJNR Am J Neuroradiol 2003, 24:147-150.

14. Isaacson G, Kochan PS, Kochan JP: Pseudoaneurysms of the superficial temporal artery: treatment options. Laryngoscope 2004, 114:1000-1004

15. Méndez JC, Sendra J, Poveda P, Garcia-Leal R: Endovascular treatment of traumatic aneurysm of the occipital artery. Cardiovasc Intervent Radiol 2006, 29:486-487.

doi:10.1186/1752-1947-6-203

Cite this article as: Rao et al.: Thrombosed traumatic aneurysm of the occipital artery: a case report and review of the literature. Journal of Medical Case Reports 2012 6:203.

\section{Submit your next manuscript to BioMed Central and take full advantage of:}

- Convenient online submission

- Thorough peer review

- No space constraints or color figure charges

- Immediate publication on acceptance

- Inclusion in PubMed, CAS, Scopus and Google Scholar

- Research which is freely available for redistribution 